\title{
A Socio-Political View of English Language Teaching in the Chinese Context
}

\author{
Yaying Zhang \\ Thompson Rivers University \\ 900 McGill Road \\ Kamloops, BC Canada \\ V2C $5 \mathrm{~N} 3$ \\ E-mail: yzhang@tru.ca
}

\begin{abstract}
In spite of the urgent need for research into the socio-political contexts of the teaching and learning of English as a second/foreign language, the predominant paradigm of inquiry into EFL in the Chinese context still focuses on the functional aspects of second language education. In order to provide a critical understanding of the larger context of the hegemony of "global English," this paper examines the teaching and learning of English in China as an integral part of the politics of the global spread of English as well as the political and ideological apparatuses of the third-world/postcolonial culture in China. Informed by Foucault's archaeological/genealogical methods, I trace the history of English language teaching in China, from colonial contexts in the $19^{\text {th }}$ century to postcolonial conditions of English language teaching at the beginning of the $21^{\text {st }}$ century. I argue that the teaching and learning of English in a third-world/postcolonial country is never a simple transparent process with clear-cut meanings. The ambiguous legacy of English language teaching, embedded in colonial/postcolonial relations, defines and complicates the connection between local specificities and the global context of the hegemony of English.
\end{abstract}

Keywords: Hegemony, English language teaching, Chinese context

\section{Introduction}

In the last few decades, intellectual work in many disciplines in the social sciences and humanities, including anthropology, cultural studies, literary criticism, and most prominently, postcolonial studies, has questioned the assumed universalisms of Western thought, and has asked how they have been produced and what other possibilities they have denied in the process. More and more scholars in these fields are being called upon to perform what Said (1994) regards as the role of the intellectual, namely, "to raise embarrassing questions, to confront orthodoxy and dogma (rather than to produce them)" (p. 11), and to challenge "easy formulas, or ready-made clichés, or the smooth, ever-so-accommodating confirmations of what the powerful or conventional have to say, and what they do" (p. 23). Thus, for example, if powerful speakers or groups enact or otherwise exhibit their authority in discourse, critical researchers will seek to know exactly how this is done by investigating the discursive structures and strategies involved in that process. To understand the discursive reproduction of power, the researcher will be engaged with both the production and reception of dominance. That is, she will examine the enactment, expression or legitimation of dominance in the production of discourses, on the one hand, and the functions, implications, consequences or results of such discourses, on the other.

In this paper, I will examine the socio-political contexts of the teaching and learning of English in the Chinese context. In spite of the urgent need for research into the socio-political contexts of the teaching and learning of English as a second or foreign language, most published studies on EFL in the Chinese context, including studies in contrastive rhetoric, still seem to be designed in such a way that researchers focus on rhetorical strategies, teaching methods, and other functional aspects of second language writing (Mohan \& Lo, 1985; Lu, 1998; Li, 1996; Cai, 1999; Liu, 2005; You, 2003). What seems lacking from this predominant paradigm of inquiry is a perspective that the enterprise of English language teaching and learning in China is intertwined with China's broader social and political relations with English-speaking countries, particularly Britain and the United States. To understand the penetration of English into the Chinese psyche in the last two centuries, from the first few sporadic missionary schools in the early nineteenth century to the blossoming of a constellation of English programs in various institutions in the early 21 st century, which usually culminate in TOEFL, IELTS, and GRE, one must investigate the teaching and learning of English as an integral part of 
the politics of the global spread of English as well as the political and ideological apparatuses of the third-world/postcolonial culture in China; one must grasp and contextualize the present construction of English as a "global" language by reflecting on the earlier spreading processes and related phenomena. Such is the nature of the phenomena I am investigating - the spread of English, the teaching and learning of English, and the larger colonial/neocolonial contexts of the spread and teaching and learning of English - and these reach through many sectors and across many planes of our post-modern experience.

\section{Frameworks for understanding the global spread of English}

There are different frameworks for understanding the global expansion of English. According to Pennycook (2000), the dominant academic line in applied linguistics on the global spread of English espouses a liberal attitude. Based on a mixture of general political liberalism and a more specific academic apoliticism, a view that academic work should somehow remain objective, this approach either denies ideological implications of the global spread of English, or suggests that they are not the concern of scholars in applied linguistics. An example of this line of thinking is Crystal's (1997) popular book English as a Global Language. Crystal claims that what he offers is "a detached account" of global English that attempts to resist "being interpreted as a political statement" (pp. vii -viii). He argues for support for the benefits of English as a global means of communication, and at the same time he does not deny the importance of multilingualism either.

However, such a view of celebrating universalism while maintaining difference seems problematic, as it tends to be reticent about the ideological implications of the global expansion of English. As Pennycook (2000) suggests, such a view, while appearing to maintain a stance of "scientific objectivity," is in fact associated with a liberal ideology that favors a capitalist market-driven "freedom-of-choice" approach in interpreting human behavior - "everyone is free to do what they like with English, to use English in beneficial ways and to use other languages for other purposes" (p. 111). More significantly, the liberal approach toward the global spread of English may have origins in "colonial-celebration," a position that "trumpets the benefits of English over other languages, suggesting that English has both intrinsic (the nature of the language) and extrinsic (the function of the language) qualities superior to other languages" (Pennycook, 2000, p. 108).

Contrary to liberal scholars like Crystal, Phillipson $(1988,2000)$ argues that there are significant relationships between global imperialism, in terms of economic, political, military, communicative, cultural and social imperialism, and the global spread of English. According to Phillipson (2000), the very term "the global spread of English" is problematic as it "refers to a seemingly agentless process, as though it is not people and particular interests that account for the expansion of a language" (p. 89). Furthermore, terms such as "global English" or "world English" "grossly misrepresent the reality of the communication experience of most of the world's population" since only a small fraction of the population of most countries in the world actually speaks English (p. 89). More seriously, such terms conceal their inherent inclusionary/exclusionary function, i.e. the use of English serves the interests of some better than others. In this sense, the view of English as a universal language can be aligned with "linguicism," which is defined by Skutnabb-Kangas as ideologies and structures which are used to legitimate, effectuate and reproduce an unequal division of power and resources (both material and non-material) between groups which are defined on the basis of language (on the basis of their mother tongue). (cited in Phillipson, 1988, p. 343)

As Phillipson (1988) suggests, while the discourse of linguicism functioned to secure the dominance of English in colonial times, liberal discursive support for the global expansion of English around the turn of the 21 st century assures the continuation of the structure of linguistic inequality in the contemporary neo-colonial world, where "the 'development' message has been carried overseas through the medium of the 'international' language, English" (p. 341). There has been no significant break with colonialist linguistic practice, since English remains in the post-colonial age the key language of multinational businesses, of administration and justice, of the media, and of science and education, etc. Phillipson observes that to facilitate learning the language, and thereby promote the interests represented by English, the English as a Second/Foreign Language profession has expanded dramatically in the last few decades, both in the West and in the Third World. In Phillipson's words, "the British empire has given way to the empire of English" (p. 342).

Compared with Crystal's “detached” perspective on the global spread of English, Phillipson's critical view may seem polemical and politically over-charged. It also tends to define geopolitical relationships of the world in terms of centre/periphery binary constructions, and thus runs the risk of overlooking the complexities of local manifestations that surround the global expansion of English. Nevertheless, it is a very significant analysis as it helps us not to lose sight of the real forces of imperialism, with which the global spread of English is intertwined, that are penetrating many economic, political, and cultural domains in complex ways.

Another way to view "global English" is through a Foucaultian perspective, i.e., to consider "global English" as a "discourse." A discourse in the Foucaultian sense is not a group of signs or a stretch of text, but statements which are enacted within a social context, which are determined by that social context and which contribute to the way that social 
context continues its existence. A discourse is a system of statements which provides a way of representing the knowledge about a particular topic at a particular socio-historical moment. In The Archaeology of Knowledge, Foucault (1972) proposes a new way of looking at archaeology:

If I situate archaeology among so many other, already constituted discourses, it is . . in order to reveal, with the archive, the discursive formation, the positivities, the statements, and their conditions of formation, a specific domain. A domain that has not so far been made the object of any analysis (at least, of what is most specific and most irreducible to interpretations and formalizations about it); but a domain that has no means of guaranteeing . . . that it will remain stable and autonomous. (pp. 206-7)

It seems that Foucault's idea is to disregard the truth of statements as well as their meaning, to map out the overarching rule systems in the thinking of whole epochs. His suggestion is to track the ordered fields of knowledge, or discursive formations, which are common to the discourses of a whole epoch, without undertaking any deep interpretations of the "real" meaning of the discourses or making a commitment as to their "truth," in the sense of correspondence to reality. Later, this archaeological approach was complemented by Foucault's "genealogy," in which the origins of discourses are studied. Foucault (1978) uses the genealogical approach in extensive studies of the development of the prison system and disciplinary surveillance. Both the archaeological and the later genealogical methods are closely knitted with the issues of power/knowledge, archaeology charting the forms of discourses and genealogy studying their power-rooted origins. Archaeology provides the distance, the detached description of the discursive formations, and genealogy the engagement, the critically committed probing of the roots of social practices. To take such a perspective implies disregarding the view of discourse as a means of transparent communication, a view within which the worth of the statements of a discourse is wholly absorbed in their truth value. To analyze a discursive formation is to weigh the value of statements, a value that is not defined by their truth, that is not gauged by a secret content but which characterizes their place, their capacity for circulation and exchange, and their possibility of transformation. Thus, it is not important or possible simply to determine what is true and what is not true. But it is possible to focus on discourses which reflect attitudes and positions, and to ask the following questions: In what contexts or situations are the attitudes and positions expressed? What interests do they serve? What consequences, both discursive and material, do the dominant representations have?

Following this "archaeological/genealogical" approach, I will not examine the truth of discourses constructed in relation to English language teaching in the Chinese context, i.e., the truth of colonial constructions of English as a superior language and contemporary liberal constructions of English as a global language, but will study how certain discourses became dominant and locate them historically. I will attempt to understand "global English" in China through historicized and localized social contexts to examine how discourses related to English are embedded in colonial and neo-colonial relations, in other words, to try to explain not only why the use of English was interpreted in terms of "global" and "universal," which, in turn, conditioned the use of English, but also how this happened in China and how discourses surrounding English in the Chinese context have come into being, and continued and changed over time.

\section{The spread of English and the discursive constructions that accompany English to China}

A great number of works on China's relations with the West in the nineteenth and twentieth centuries provide a chronicle of the rapid changes in China as a result of increasing Western influence over and penetration into China's economic and political life (e.g., Bickers, 1999; Fairbank, 1983; Barlow, 1997). Though much has been written about foreign influence on China in the last two centuries, surprisingly little attention has been given to the role of English in this influence, given the fact that English language teaching played an important part in China's semi-colonial history before the founding of the People's Republic of China in 1949 and in China's modernization process in the last twenty-five years.

The existing writings in relation to English instruction in China, whether they are travel accounts by visiting foreigners who have taught English in China (e.g., Salzman, 1986; Theroux, 1988; Jochnowitz, 1986, Johnston, 1996; Hill, 1997; Myers, 2002), or studies by researchers in second language education (e.g., Matalene, 1985; Burnaby and Sun, 1989; Scovel, 1983; Ross, 1993; Barlow and Lowe, 1985; Xie and Derwing, 1996; You, 2003), have not paid much attention to the fact that the history of English and English language teaching in China in the past two centuries is inseparable from the broader social and political relations between China and English-speaking countries, especially Britain and the United States. As these broader relations developed and changed over time, so too did the conditionings as well as discursive constructions of English language teaching in China.

According to Donald Ford (1988) and Robert Bickers (1999), English language teaching was introduced to China in the nineteenth century in the context of growing foreign domination (see also Liu, 1999; Austin, 1986; Fairbank, 1983). Initial contacts between China and Western nations revolved around trade between the West and Chinese coastal cities of the southeast in the eighteenth century. Though the Portuguese initiated this trade, they were gradually supplanted by the British. In 1840, the British started the Opium War with China after the latter demanded that Britain stop selling opium in China. The war resulted in a humiliating defeat for China, which was forced to give up Hong Kong and open 
other ports to foreign traders. From this point on, Western powers demanded that China open more of its territory to trade and allow foreigners virtually unlimited access to China. Whenever China refused to acquiesce to new demands, Western forces invaded China, heaping one defeat upon another. By the end of the nineteenth century, a scramble was underway to carve China up into foreign spheres of influence.

It was in this context of unequal relations between China and Western powers that the English language arrived in China. Along with foreign gunboats and troops came merchants, diplomats, and missionaries, each with their own agendas. But all brought to China their native languages, the most influential among which was English. Beginning with coastal colonies and treaty ports, the English language began to penetrate and spread throughout China. In the mid-nineteenth century, mission schools were established in China, which would not have been possible without the protection they received from the first unequal treaties forced on China in the 1840s by the British. These treaties usurped territory from China, opened port cities to trade and guaranteed that the activities of foreigners would not be regulated by China (Ford, 1988; Bickers, 1999; Austin, 1986; Fairbank, 1983).

During this period, some missionaries believed that the study of English could pave the way for Christianity by allowing Chinese people to more easily grasp the key concepts of the Christian worldview and by enabling them to read the English Bible and other religious materials in their original form. They viewed English language training as the path of least resistance through which to bring the hearts and minds of the Chinese people to God. Others promoted English as a way to introduce Western ideas to China and as a way to undermine Chinese traditions that they opposed. Still others carried this argument even further, advocating English instruction as a means to break down what they considered as "the superstitious and heathen Chinese ways of life" (Ford, 1988, p. 14). This was the period in which Christianity and modern Western practices were perceived as the savior of China, a country stuck far back on the inevitable upward march of progress. Thus, from the beginning, English language instruction was the handmaid of colonialism. This missionary element in English language teaching is particularly important in understanding the discourses on English and how English as a "global" language is not a neutral phenomenon, but laden with colonial implications.

It was also in this period when the Orientalist approach to China reached its height, when Europe colonized not only parts of China, but also knowledge about it. That is, the condescending and negative views of the missionaries towards China led to the "establishment of a large body of knowledge as part of the great colonial archive of knowledge about the Other" (Pennycook, 1998, p. 169). Various discursive techniques for dealing with those positioned as Other also emerged, such as the pervasive tendency to formulate the world through binaries - e.g., Self versus Other, enlightened versus backward, modern versus unchanging, good versus evil - which intensifies notions of Otherness. The development of such views was not an isolated process, but part of the broader process of colonization in the nineteenth and twentieth centuries. As Said (1978) demonstrates, there are a number of features which occur again and again in texts about colonized countries. These features cannot be attributed simply to the individual author's beliefs, but are rather due to larger belief systems structured by discursive frameworks, and are given credibility and force by the power relations found in imperialism. Colonial discourse does not therefore simply refer to a body of texts with similar subject matter, but rather refers to an institutional set of practices and rules which produced those texts and the methodological organization of the thinking underlying those texts.

Pennycook (1998) gives an extensive discussion of the series of stereotypes in Western representations of China: "the exotic and eternal kingdom, the underdeveloped and backward, the paradoxically juxtaposed old and new, the crowded, dirty and poverty-stricken life, the smiling or inscrutable exterior hiding either bad intentions or misery . . . and so on." (p. 172). Although such constructions occur across a broad range of writing, one domain which has particular implications for this paper is writings by and for English language teachers in China. These writings produce discourses of Self and Other, that construct English and speakers of English in particular ways. Such cultural constructs still play a major role in how English language teaching is constructed and practiced: from the native speaker/non-native speaker dichotomy to the images of English as a global language and assumptions about speakers of English and their cultures.

A contemporary example of such constructs in relation to English language teaching in China could be seen in the discourse on English and native/nonnative speakers of English on the website of ELIC (English Language Institute/China), an organization that yearly sends Christian teachers, mainly from the United States, to teach English in Chinese universities across the country. Apart from clearly supporting a simple argument about the superiority of English, the view of the richness of English at this website also ascribes certain qualities to native speakers of English the idea that native English speakers are role models who have the power to influence and save the unenlightened. It appears that native speakers are portrayed as superior not only because of their knowledge of the English language, but because of certain higher human qualities granted to them by the fact that they are native speakers of English. The following excerpts are taken from recruitment messages, supposedly addressed to future English instructors, which appeared on the ELIC website in April 2004: 
ELIC (English Language Institute/China) first broke ground in 1982 by sending our first team of teachers into China .... Your passion to serve these people and bring them excellence in the English language will provide opportunity for you to influence each individual, one life at a time.

Deep within China's Himalayan frontier . . . the English language is revered. . . You'll provide these students with a language they so desire to learn and a hope they so passionately seek . . . .

Imagine playing a major role in their process of a major life transformation. You don't need to speak Chinese. You don't need to be a teacher by trade. You just need to be willing . . . . Thousands of Chinese students await our arrival. Will you be there to offer them what they need most?

It's your chance to impact two generations - shepherds and the sheep - with your language and life.

We desire to educate and train superbly competent teachers of English, the global language of modernization and development, to enable those in developing countries to maximize their contribution to the holistic progress of society.

Such descriptions of English and its native speakers bear much resemblance to colonial binaristic constructions of Self and Other and show how constructs of the superiority of English play an important role in how English is understood as a language and how the native speaker in particular is portrayed. What is interesting in these descriptions is the assumed fusion of knowledge of the English language and the superiority of Self: it is the positive of the negative template of the Other - the non-native speaker of English - that provides moral definitions of the Self.

It is not my interest or intention here to vilify ELIC, but, as Pennycook (1998) suggests, such discourses in and around English have serious consequences. First, one of the most insidious constructions that have emerged from the glorification of English is the dichotomous relationship between native speakers and non-native speakers, with the former elevated over the latter. The way in which English is constructed as a superior language, when coupled with a belief that to know English is to have a better way of understanding and describing the world, makes the native speaker of English not merely a supposedly better teacher of English but also someone endowed with superior knowledge about the world. Second, the language on the website of ELIC (re)produces colonial constructions of English as a superior language for Western readers and English language teachers; this representation is intertwined with the larger "regime of representation" of Self and Other.

To be sure, a person's present understanding of the world is, of necessity, influenced by notions and knowledge she identifies with in subtle and significant ways, and one's perspectives on the world are never innocent of motives and motivation embedded in one's own historical moment and cultural positioning. If you ask the Chinese students, for example, they will almost surely come up with very different views, although perhaps also problematic, of their country, themselves, and their relationship to English as a global language. What is more important is to recognize the connections between ELIC's representation of English and its speakers and the profession of English language teaching. ELIC's mission to send English teachers to China is significant, as it is exactly such representations that construct part of the work and the knowledge of the Western English teacher in China. It is highly plausible that representations of English as a superior language can put into play particular approaches to teaching, and such fixed and essentialized notions of a language and its speakers can hold sway in many domains of English language teaching, and English language teaching - its practice, policy, institution, discipline - is a central contributor to the construction of English as a global language.

\section{Modern-day renditions of "Global English" in China}

As has been said before, English language teaching in China and its relationship with constructs of Self and Other are contingent upon the broader social and political relations between China and the West. The importance of English was drastically reduced by the Chinese government, during the 1950s and 1960s, when the Cold War chilled Sino-American relations and the Soviet influence was at its height. However, English came back into Chinese life with dramatic speed when the Cold War was over. Large numbers of foreigners began to visit and reside in China as part of a new open-door policy initiated by Deng Xiaoping, whose goal was to speed up the modernization process in China. In particular, since the reestablishment of diplomatic relations between China and the United States in 1979, a host of American teachers, students and scholars have visited or worked in China.

Those English teachers sent from Western countries such as the United States and Britain become significant agents in the spread of English, taking over where colonial education left off. As Lam (1999) reports:

In recent years, there has been a resurgence of interest [in China] in the hiring of expatriates as teachers to provide more "native" models of the language to students whose proficiency in English has been widely considered inadequate in meeting the requirements of higher education and the workplace. (p. 378)

Initiated by colonial domination in the past and propelled by commerce, science, and technology in the present, the spread of English in the world has always been facilitated through instruction in the classroom, as witnessed by the rise of the English language teaching profession. Though missionary schools clearly failed in their primary goal of 
converting masses of Chinese to Christianity, their educational activities left an important legacy in China. For instance, they initiated a pattern of practices of authoring and introducing textbooks and teaching methodologies, which the new generation of foreign teachers seem to have inherited. However, English language teaching in the new era appears in a new guise. Since English language teaching in China is always part of the larger geopolitical picture that defines China's relationship with the West, the spread of English in this period seems to go parallel with the spread of the culture of international business, consumerism, and technological standardization, which inevitably brings back the superior image of the West. As Phillipson (1988) explains, "the higher and better view of the West is now less represented by the gun and the Bible than by technology and the textbook. Western products still come wrapped in a Western language and in Western thought" (p. 341).

What I intend to do in the rest of this paper is to look at how China responds to "global English" and how China's responses are related to the operation of the hegemony of "global English." As Gramsci (1971) suggests, hegemony works when the dominated can be influenced in such a way that they accept dominance as natural, and act in the interest of the powerful out of their own free will. It appears the essence of hegemony that inequities are internalized or taken for granted by both the dominant and dominated groups as being natural and legitimate. The concept of hegemony, and its associated concepts of consensus and acceptance, suggests that many forms of dominance appear to be jointly produced through intricate forms of social interaction, socio-cultural values and assumptions, and discursive practices. In the case of English in China, consensus and acceptance in the form of Chinese support for the dissemination of English and Chinese students' participation in the process are part of the sources that contribute to the global hegemony of English. Thus, we should view the global dominance of English not ultimately as a direct consequence of imperialism but rather as partly a product of the local hegemonies of English. Any concept of the global hegemony of English must therefore be understood in the context of local responses - indeed, the global hegemony would have no material definitions without local responses.

In contemporary Chinese life, English has taken a position of unprecedented importance. It is seen as an essential tool in developing and changing the core of the country's economic system. As Sun (1999), a Chinese writing instructor, comments in the preface to his Writing in English, a textbook for Chinese college students, English has become a popular language for international communication in China. He describes English in China in terms of the role it plays in China's changing relationships with the rest of the world:

With the acceleration of the pace of reform in China, the exchange and cooperation between our country and the rest of the world, in the areas of economics, culture, education, and politics, have become more frequent and prevalent. In this process, the role of English as a means of communication has become more and more prominent. In order to assist the spread of English, to improve the English proficiency of the whole society, to meet the needs of the development of situations, English courses have been generally offered in elementary and high schools; various kinds of English programs have been set up; adult education in English has spread all over the country; various kinds of media such as radio and television have also made great contributions to the improvement of English proficiency of people from all walks of life. (p. 1)

Sun's comments are revealing in that they illustrate the complex network of apparatuses in China that accept and support the dominant role of English as a language of international communication. On the one hand, this network cooperates with colonial discursive constructions of English to reinforce the prominent role of English in international communication; on the other hand, it reveals the tension between global orientation and national identity in the modern era. This contradictory logic of modernity shows how the global status of a nation is created through the production of universalism and its appropriation, whether as a modernizing agenda or as a statement of world citizenship. While contributing to a larger position of the global hegemony of English, this complex network also becomes the site for the creation of a local hegemony, one consequence of which is that thousands of young men and women are inspired each year to either enroll in English programs within China or become part of the liu xue trend, i.e., the trend to go abroad to study, with the firm conviction that English can be their passport to a better life.

The Chinese government plays a central role in this local hegemony: it becomes the dominant "centripetal" force, to use Bakhtin's (1984) term, through dictating policies and systems to be implemented to facilitate English teaching and learning countrywide. In order to advance the country's political and economic interests, the central administration has put a predominant emphasis on the teaching, learning, and testing of English. Performance in compulsory English study from early secondary school on and scores on national examinations, including compulsory English, continue to be critical factors for entrance into post-secondary education positions. Meanwhile, scientists, technicians, teachers, and many other professionals are required to master English in order to read literature about advanced technology and management from developed countries. To further encourage English learning, various gate-keeping institutions and exam systems were established; for example, the demonstration of a certain level of English proficiency, usually through exams, becomes a necessity for promotion in many academic and professional fields. In other words, English 
proficiency becomes a critical factor for professional success, a gateway to many social and material benefits. It also becomes the hallmark of an educated, cultured, and modern person and hence a marker of social position and prestige.

To some extent, English in China has attained a similar status to English in the colonial Kenya Ngugi (1986) describes in his Decolonizing the Mind. According to Ngugi, in the entrance requirements at university level in Kenya a high grade (a credit) rather than a pass in English was required. "Thus the most coveted place in the pyramid and in the system was only available to holders of an English language credit card. English was the official vehicle and the magic formula to colonial elitedom" (p. 115). Although there are drastic differences between scenarios in Kenya and China, i.e., Ngugi's Kenya was under colonial rule while China today is under the force of globalization, elitist, centralizing policies and regulations, as Ngugi suggests, may become a crucial instrument to sustain and uphold inequalities on different levels, between the West and colonial/postcolonial countries as well as between the elite in colonial/postcolonial countries and the majority who are deprived for various reasons.

\section{Conclusion}

In this paper, I have discussed the historical contexts of English language teaching in China and their modern-day renditions, tracing connections between English language teaching and learning in China and the global context of colonialism and neo-colonialism. Informed by Foucault's archaeological and genealogical methods, I considered the political and ideological contexts in which English spread to China and examined how the assumptions about English, its native/nonnative speakers, and about China and Chinese learners that accompanied the spread of English to China in the nineteenth century manifest themselves in the postcolonial age, when Western teaching methods are imported under the label of science and foreign teachers continue to construct the English language, China and Chinese students in ways that are reminiscent of the larger regime of representation of the Other.

I want to end this paper by emphasizing a few points. First, the teaching and learning of English in a third-world/postcolonial country is never a simple transparent process with clear-cut meanings; this complexity only bespeaks the resilience of implications about English language teaching and learning in the Chinese context. Second, from Western constructions of Self and Other in relation to English language teaching in China, as seen in the language on the ELIC website, to Chinese government's policies regarding English language teaching and learning, we can see that English in China is indelibly linked with the (re)production of neocolonial relations between China and the West. This ambiguous legacy of English language teaching embedded in colonial relations defines and complicates the connection between local specificities and the global context of the hegemony of English. Third, I insist that "global English," no matter how much discursive construction may be involved in its representations, is not in itself entirely and exhaustively discursive. "Global English" for many non-native speakers exists as a living presence, a reality to be dealt with in earnest. And finally, I hope this paper may contribute to a more complex understanding of the learning experiences of Chinese students, both those from China and those in China, who have been much of the focus of discursive constructions of them as foreign or ESL students in conventional scholarship in second language education.

\section{References}

1959. Toronto: University of Toronto Press.

Austin, A. J. (1986). Saving China: Canadian Missionaries in the Middle Kingdom 1888.

Bakhtin, M. M. (1984). Speech genres and other late essays. Minneapolis, MN.

Barlow, T. E. (1997). Formations of colonial modernity in east Asia. Durham, NC: Duke University Press.

Barlow, T. E., \& Lowe, M. N. (1985). Chinese reflections: Americans teaching in the People's Republic. New York: Praeger Publishers.

Bickers, R. (1999). Britain in China. Manchester: Manchester University Press.

Burnaby, B. \& Sun, Y. (1989). Chinese teachers' views of Western language teaching: Context informs paradigms. TESOL Quarterly, 23 (2), 219-238.

Cai, G. (1999). Texts in contexts: Understanding Chinese students' English compositions.

Crystal, D. (1997). English as a global language. Cambridge: Cambridge University Press.

English Language Institute/China. China university teaching program. Retrieved April 5, 2004 from: http://www.elic.org/china-univteach.html.

Fairbank, J. K. (1983). The United States and China. Cambridge, Mass.: Harvard University Press.

Ford, D. (1988). The twain shall meet: The current study of English in China. London: McFarland \& Company Publishers.

Foucault, M. (1972). The archaeology of knowledge. New York: Harper Colophon.

Foucault, M. (1977). Discipline and punish. New York: Random House. 
Gramsi, A. (1971). Selections from the prison notebooks. London: Lawrence and Wishart.

Hill, Justin. (1997). A bend in the Yellow River. London: Phoenix House.

In C. Cooper \& L. Odell (Eds.), Evaluating writing (pp. 279-297). Urbana, IL: National Council of Teachers of English. Jochnowitz, G. (1986). Teaching at a provincial Chinese university. American Scholar. 55 (4), 521-527.

Johnston, B. (1996). Boxing with shadows: travels in China. Melbourne: Melbourne University Press.

Lam, W. (1999). The question of culture in global English-language teaching: A postcolonial perspective. In L. Liu (Ed.), Tokens of exchange: The problems of translation in global circulations (pp. 375-397). Durham, NC: Duke University Press.

Li, X. M. (1996) “Good writing” in cross-cultural context. Albany, NY: State University of New York Press.

Liu, L. (Ed.). (1999). Tokens of exchange: The problems of translation in global circulations. Durham, NC: Duke University Press.

Liu. L. (2005). Rhetorical education through writing instruction across cultures: A comparative analysis of select online instructional materials on argumentative writing. Journal of Second Language Writing. 14, 1-18.

Matalene, C. (1985). Contrastive rhetoric: An American writing teacher in China. College English. 47, $789-808$.

Mohan, B., \& Lo, W. (1985). Academic writing and Chinese students: Transfer and developmental factors. TESOL Quarterly. 19 (3), 515-534.

Myers, M. (2002). Adrift in China. London: Summersdale Publishers.

Ngugi, W. T. (1986). Decolonising the mind: The politics of language in African literature. London: James Curry.

Pennycook, A. (1998). English and the discourses of colonialism. London: Routledge.

Pennycook, A. (2000). English, politics and ideology. In T. Ricento (Ed.), Ideology, politics and language policies (pp. 107-120). Philadelphia: John Benjamins Publishing Company.

Phillipson, R. (1988). Linguicism: structures and ideologies in linguistic imperialism. In T. Skutnabb-Kangas, \& and J. Cummins (Eds), Minority education: From shame to struggle (pp. 339-358). Philadelphia: Multicultural Matters.

Phillipson, R. (2000). English in the new world order. In T. Ricento (Ed.), Ideology, politics and language policies (pp. 87-106). Philadelphia: John Benjamins.

Ross, H. (1993). China learns English. New Haven: Yale University Press.

Said, E. (1978). Orientalism. London: Routledge.

Said. E. (1994). Representations of the intellectual. New York: Pantheon.

Salzman, M. (1986). Iron and silk. New York: Random House.

Scovel, T. (1983). The impact of foreign experts, methodology and materials on English language study in China. Language Learning and Communication, 2 (1), 83-91.

Sun, L. (1999). Writing in English. Shanghai: Shanghai Foreign Languages Education Press.

Theroux, P. (1988). Riding the iron rooster: By train through China. New York: Putnam.

University of Minnesota Press.

Xie, M.M., \& Derwing, T. M. (1996). Adult EFL in community schools in Beijing, China. Journal of Multilingual and Multicultural Development, 17, 385-395.

You, X. (2004). "The choice made from no choice": English writing instruction in a Chinese University. Journal of Second Language Writing, 13, 97-110. 